\title{
A Game-Based Learning Approach to Improve Students' Spelling in Thai
}

\author{
Krittiya Saksrisathaporn \\ College of Arts, Media and Technology \\ Chiang Mai University, Chiang Mai, Thailand 50200
}

\begin{abstract}
The problem of misspelled Thai words written in social media is increasing rapidly by youth in Thailand. To decrease the number of misspelled Thai words and improve the learning achievement for Thai youth, a first-person 3D mobile game was developed. The game is run on an Android smartphone applying a gyroscope sensor. This game has 3 levels in 5 stages. The learning achievement is evaluated from 37 players' pre- and post-test scores, who are bachelor's degree students of Animation and Game, College of Arts, Media and Technology, Chiang Mai University, Thailand. The data were statistically analysed by a paired sample t-test. Pre- and post-test scores were weakly and positively correlated $(r=0.666, p<0.001)$. There was a significant average difference between pre- and post-test scores (t36 = 11.776, $\mathrm{p}<0.001)$. On average, post-test scores were 15.027 points higher than pre-test scores $(95 \%$ CI $[-17.615,-12.439])$. The results of the research show that the game-based learning approach significantly improved players' learning achievement in misspelled written Thai words.
\end{abstract}

Keywords-Game for learning; game-based learning; mobile game; paired sample t-test; Thai; misspelled words

\section{INTRODUCTION}

Thai is the national language of Thailand, and it is intrinsically connected and interrelated to the culture of the Thai people, their identity, and Thai society. Thai people should understand the meaning of words and be able to use them correctly according to the principles of the Thai language, whether or not this is in the form of listening, speaking, reading, or writing. Although nowadays, many Thai youths have problems with spelling in writing, and misspelled words in writing are often seen on social media platforms, such as Facebook, Twitter, and LINE. This problem is increasing rapidly, and more so among the Thai youth.

Presently, using tools of communication in the digital era is inevitable. Mobile computing devices such as mobile phones have now evolved into the era of smartphones. Today, we possibly spent for 135 minutes per day on social media. People aged 16 to 24 spend the most time on social media - 3 hours and 1 minute daily [1]. Many people also spend time talking, communicating, studying online, or playing computer games on smartphones, which makes these devices extremely popular among mobile phone users today. Games for serious games or games for learning are tools that are easily accessible by people in the smartphone era, especially young people. Games for learning (G4L) and Game-based learning (GBL) have similar meanings and goals. In this paper, GBL was tested in a classroom while G4L may be implemented in the future for not only the purpose of the target group but for all Thai people.
The objective of the research, was to promote spelling and word recognition learning, and a first-person 3D mobile shooting game named "The Herd of Calf teach Thai" was developed. The game is run on a smartphone with an Android operating system by applying a gyroscope sensor [2]. The proposed game was designed to help motivate students to learn Thai and practice writing Thai by themselves by playing the game rather than memorizing words because language is a subject of frequent practice; and it will be more effective in the long-term. This mobile game aims to support students and players to learn and remember the often-misspelled Thai words with more interest and enthusiasm and to increase the resources that may help aid students in self-study. To further enhance this process the game was designed with vivid graphics.

The player must find the Thai consonants or vowels (letters) by turning the device, also known as a gyroscope control, then hit a shot to shoot a letter to the word until the correct word is formed. This game has 5 stages with 3 levels of difficulty. The player must find the Thai consonants or vowels (letters) by turning the device, also known as a gyroscope control, then hit a shot to shoot a letter to the word until the correct word is formed. This game has 5 stages with 13 words at each stage, including 3 levels of difficulty at each stage. To win the game, the player must pass 5 stages with at least 7 points in each stage. Many students spend time on YouTube video tutorials and other online materials hence find useful information on their own rather than in the classroom [3].

The prototype game was tested and evaluated with a student population, who are at the pre-working age, have a lot of energy, like playing games, like social communication, and mobile games. The evaluation used a paired sample t-test, which is suitable for the population sample data to compare scores before and after learning. Based on the pre- and posttest results, of the population, which were carried out under identical testing conditions, it was found that pre- and post-test scores were weakly and positively correlated $(r=0.666, p<$ $0.001)$. There was also a significant average difference between pre- and post-test scores $(t 36=-11.776, p<0.001)$. On average, post-test scores were 15.027 points higher than pre-test scores (95\% CI [-17.615, -12.439]).

The game has several detailed steps in the game-making process that involved and needed integrated knowledge to produce the game. However, there are still opportunities to develop further the game, including some game techniques and art elements that can even be improved. System development can also be enhanced to collect playing statistics such as 
identifying wrong and correct words to do further research in the future. To continue developing the game in other word categories or other Thai languages such as the Lanna language, including digital game development, which can work on a commercial.

The remainder of this study is structured as follows: Section II describes the background and related work. Section III presents a flow of the research methodology. Section IV presents the game design and development. Game testing and evaluation are discussed in Section V. Lastly, conclusions and future perspectives are discussed in Section VI.

\section{BACKGROUND AND ReLATED Work}

\section{A. Thai Commonly Misspelled Words}

According to Sanom Krutmueng, 2014 [4], it was stated that "Currently, writing wrong Thai words is considered a very important problem for Thai youth", which is partly due to the creation of non-words and commonly misspelled words in everyday communication and writing by teenagers. This problem is becoming even more apparent in communication on social media, including listening, speaking, reading, and writing. There are also problems arising from the use of transliterated words that are commonly written incorrectly because the Thai language is a tonal language and is different from other foreign languages. Many spelling errors are related to pronunciation [5]. When incorrect writing is used continuously it results in new words being created that do not comply with Thai grammar, which creates ongoing problems in communication.

Misspelled words can be divided into two types [6]; [7]; [8]; [9] and include non-word misspelling errors and real-word misspellings. Real-word misspellings are the combination of characters of consonants, vowels, and tones, and create other words with meaning and appear in the dictionary. However, that word is not the word that the author intended to write [10] and is considered another type of misspelling that may cause the structure or meaning of the sentence to be distorted [7]. Misspelling can cause either a non-word error or an error, which is a real word but not the intended one. A non-word misspelling error is easier to detect by comparing it with a word list in a dictionary, while a real-word misspelling error cannot be detected with this method [11]. For example, "กระเพรา" (basil) is a real-word misspelling error in Thai while "กะเพรา" is a corrected word.

In 2019, Ronnayut found eight common mistakes in Thai misspelling from a random experiment with 1000 first-year students [12]. Moreover, in the same year, Rungnapha analyzed the misspellings in Thai and suggested that various teaching and learning innovations should be used to solve the problems of misspellings in order to improve academic achievement and performance [13].

\section{B. Game for Learning and Game-based Learning}

Currently, there are many types of games, such as board games, card games, video games, and digital games [14]. These games can be type constructed as an entertainment game, educational game, game-based learning, game-based pedagogy simulation-based games, serious games, etc. [15].
An action game is a game that offers high-intensity action as the primary attraction. The reflex response is the primary skill needed to play these games well. The most common action games are shooters (Doom) and stealth (Metal Gear). The puzzle games are games that offer puzzles as the primary attraction. These games are mostly released on low budgets via the web. One of the most successful puzzle games is the famed Tetris, Lemmings, and Minesweeper [16]. Another example, Hangman, is a word guessing game, played by at least 2 or more players. One player sets 1 word, phrase, or sentence, and the other players try to guess that word by selecting letters or numbers within a limited time.

Presently, modern games are Multiple Game Types and Game Genres Combined. First-person shooter (FPS) is a video game genre centered on gun and other weapon-based combat in a first-person perspective, that is, the player experiences the action through the eyes of the protagonist. The genre shares common traits with other shooter games, which in turn makes it fall under the heading action game. Recently, Nintendo's beloved Mario of Super Mario Bros went from humble beginnings as a simple side-scroller platform to now, where the Super Mario has mostly deviated from puzzle and adventure genres to a first-person Super Mario Bros shooter [17]. For example, the action game named Eliminate Gun Range, which is a target shooting game, there is a way to play in which players aim and shoot all targets in the allotted time.

According to Lorenz, 2015 [18] people who play video games have better memory and strategic planning capabilities compared to those who do not play video games. Additionally, in Jotham Msane, 2020, it was stated that students who like to play computer games are likely to succeed in programming [3]. In 2014, Andre proposed a method of a serious game to test the "Clean world" game. The learning of games occurs within multiple mechanisms, such as mini-games, puzzles, and quizzes played in parallel to the main game environment [19]. According to Becker, in 2014, she proposed a comparison table between the Game for Learning (G4L) and GBL. G4L is a game designed specifically with some learning goals in mind while GBL is the process and practice of learning using games. G4L is used for learning something while GBL is used to improve learning and to increase learning effectiveness, while both focus on content that what we are learning. However, GBL focuses more on learning objectives with the question of how to learn [15].

Educational games or edutainment games have been used as a tool for centuries and is much more attractive and interesting, and results in active learning rather than passive learning through textbooks and theory [20]. Game-based learning has been identified as an effective approach to making learning activities engaging and playful [21] serious game, and a serious game has become a hot topic in training and education as shown in the abundant academic research since 2012 [22]. Although, most digital game-based learning available in the market does not focus on graphics or level design.

Mobile devices have also become widely popular because they are easy to use, portable, and can support various applications. Many principles are considered in designing and developing these digital educational games, and many researchers focus on mobile game-based learning to enhance 
the learning skills of students as interactive games enable intuitive content to be delivered directly to students through their devices. However, most education game-based learning is simple in both graphic and level design [14].

Up until now, there has quite a lot of research carried out on the Thai language while empirical research on digital game types for the Thai language is still scarce, should create innovative teaching and learning to solve a wide variety of problems of often written errors in Thai [13]. In addition, there are only a few other resources that can help students or young people learn Thai by themselves.

\section{Research Methodology}

As shown in Fig. 1, the research started with a literature review and discussion with the teachers who teach Thai at Montfort College, a high school in Chiang Mai, Thailand. As mentioned in the introduction section, some problems were highlighted with incorrect writing and misspelled words. Game for Learning or Game-based learning were some of the approaches suggested. Moreover, commonly misspelled words in Thai writing was one of the topics that were selected for content to create a prototype game. To achieve the goal of improving knowledge in Thai writing, it was ascertained that the game needs to have a range of different levels to practice effectively. In this study, Unity software was a selected tool to develop the game. The game is divided into five stages with three levels at each stage. The game was tested and evaluated by 37 players. All game development process is detailed in the next section.

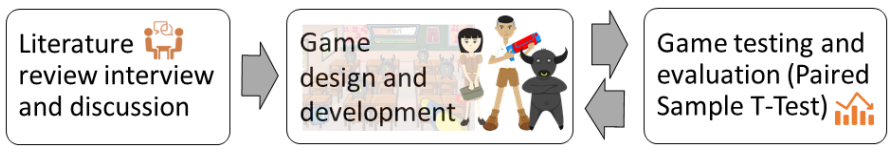

Fig. 1. Research Methodology.

\section{Game Design and Development}

A 3D mobile game was designed and developed that has an enhanced graphic design and provides an interactive playable game design for the player's experience. Player experience as an individual experience goes beyond playability and game usability [23]. In this case, the 3D game was designed and developed by using Adobe Photoshop and Unity software. The Unity software is a game engine for developing 2-dimensional (2D) and 3-dimensional (3D) games, which can work on two platforms, Windows and OSX [14]. The popular 2D game name "Gardenarium" by Paloma and Kyler (2017) [24] with the support of KO-OP [25] was also made by Unity software. The game is designed from action games combined with puzzle games. Most people, even those who are not gamers, know how to play both games. The action game "Eliminate: Gun Range", is a first-person shooter game, with the aim to shoot all targets in the allotted time, and uses Gyroscope control as the controller. Moreover, this game is combined with the classic letter guessing game "Hangman".

In this study, 65 often misspelled Thai words were selected for the game, most of them are real-word spelling errors. By dividing all the words into three groups: 1 syllable, 2 syllables, and 3 syllables, the criteria for selection of the 65 words was that the word is often seen or used in daily life and a hint was able to be set.

Game level design is divided into 5 stages, and each stage has three levels, with hints assigned to players. The first level of each stage is easy to give the players familiarity with how to play and control fire first. This creates incentives for playing and encourages them to not give up as they work up to the next level which will get harder and harder with new random words with more syllables added until the last level. Level 3 is the hardest level of each stage, and then players start the next stage on the first level again. This makes the gameplay dynamic between hard and easy. In each level, the player needs to remember the words before they can pass from one level to the next. The player needs to pass the first stage until the last stage by unlocking each level. To pass each level, players must complete the missing word within the time limit. The structure of the game levels at all stages is detailed in Table I.

The difficulty of the game depends on three factors: first, the number of syllables. Second, the time is limited, and finally, the ability of the enemy (monster), which is the calf herd. Additionally, in each level of the stage, the word appears randomly in a group so that the players are not bored and can not memorize the sequence of words to be played to increase the challenge for players. In the word manipulation, an algorithm was written to randomize the words by dividing them into 3 groups randomly at each level (see Fig.2).

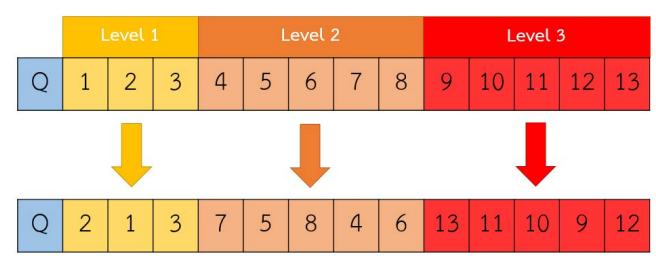

Fig. 2. Example of words Random in 3 Levels.

As shown in Fig. 3, the game flow or flowchart of the game starts with a menu selected which consists of how to play, stage selection, gameplay, and game result display. The gameplay starts playing from stage 1 level 1 to stage 5 level 3 . The score will be given as follows: if correct $>3$ words - the player gets 1 star $(\hat{\xi}),>8$ words the player gets 2 stars $(\hat{i} \boldsymbol{\xi})$, and if the player can correct all words (13 words) he/she will

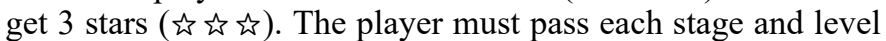
to unlock the next stage until the game is won, players must also correct more than or equal to 7 words ( $>=7$ Word) within the time or life limits. The game will end when the player or score does not pass at each level 3 times.

As shown in Fig. 4, 5 and 6, to play the game, the player needs to fill in the incomplete letters by turning their mobile device around to find and shoot the monster with the correct letter attached to it. The player can remove letters from the latest one added and continue backward in case of shooting the wrong one. The player will need to complete each word within the set time. As aforementioned, the stage will end when the player completes all 13 words or is unable to complete one of the words in time. 
TABLE I. Game Level Design

\begin{tabular}{|c|c|c|c|c|c|c|}
\hline & $\begin{array}{c}\text { Level } 1 \\
1 \text { syllable }\end{array}$ & & $\begin{array}{r}\text { Leve } \\
2 \text { sylla }\end{array}$ & & $\begin{array}{l}\text { Leve } \\
3 \text { sylla }\end{array}$ & \\
\hline \multirow{4}{*}{$\begin{array}{c}\text { Stage } \\
1\end{array}$} & Word count: 3 & \multirow{4}{*}{$\begin{array}{l}\text { ฉัน, } \\
\text { ใย, } \\
\text { โล่ }\end{array}$} & Word count: 5 & \multirow{4}{*}{$\begin{array}{l}\text { กะเพรา, } \\
\text { กันแสง, ศีรษะ, } \\
\text { กระทง, มงกุฎ }\end{array}$} & Word count: 5 & \multirow{4}{*}{$\begin{array}{l}\text { ฉะเชิงเทรา, } \\
\text { พิสมัย, จระเข้, } \\
\text { มัสมั่น, นกพิราบ }\end{array}$} \\
\hline & Alphabet time: $20 \mathrm{~s}$ & & Alphabet time: $15 \mathrm{~s}$ & & Alphabet time: $10 \mathrm{~s}$ & \\
\hline & Word time: $40 \mathrm{~s}$ & & Word time: $45 \mathrm{~s}$ & & Word time: $50 \mathrm{~s}$ & \\
\hline & Monster: idle & & Monster: idle & & Monster: idle & \\
\hline \multirow{4}{*}{$\begin{array}{c}\text { Stage } \\
2\end{array}$} & Word count: 3 & \multirow{4}{*}{$\begin{array}{l}\text { โน้ต, } \\
\text { ผลัด, } \\
\text { หงส์ }\end{array}$} & Word count: 5 & \multirow{4}{*}{$\begin{array}{l}\text { ภูตผี, นิมนต์, } \\
\text { ทรวดทรง, } \\
\text { ทรุดโทรม, ดอกจัน }\end{array}$} & Word count: 5 & \multirow{4}{*}{$\begin{array}{l}\text { เทศกาล, โทรทัศน์, } \\
\text { เบญจเพส, } \\
\text { กรรมพันธุ์, อนุญาต }\end{array}$} \\
\hline & Alphabet time: $20 \mathrm{~s}$ & & Alphabet time: $15 \mathrm{~s}$ & & Alphabet time: $10 \mathrm{~s}$ & \\
\hline & Word time: $35 \mathrm{~s}$ & & Word time: $40 \mathrm{~s}$ & & Word time: $45 \mathrm{~s}$ & \\
\hline & Monster: idle, walk & & Monster: idle, walk & & Monster: walk & \\
\hline \multirow{4}{*}{$\begin{array}{c}\text { Stage } \\
\mathbf{3}\end{array}$} & Word count: 3 & \multirow{4}{*}{$\begin{array}{l}\text { แก๊ส, } \\
\text { ไซรั, } \\
\text { เกร็ด }\end{array}$} & Word count: 5 & \multirow{4}{*}{$\begin{array}{l}\text { พิสูจน์, รื่นรมย์, } \\
\text { เกษียณ, เดียดฉันท์, } \\
\text { เศร้าโศก }\end{array}$} & Word count: 5 & \multirow{4}{*}{$\begin{array}{l}\text { อานิสงส์, } \\
\text { กระจิดริด, อุปสรรค, } \\
\text { ภาพยนตร์, เผด็จการ }\end{array}$} \\
\hline & Alphabet time: $15 \mathrm{~s}$ & & Alphabet time: $15 \mathrm{~s}$ & & Alphabet time: $10 \mathrm{~s}$ & \\
\hline & Word time: $30 \mathrm{~s}$ & & Word time: $35 \mathrm{~s}$ & & Word time: $40 \mathrm{~s}$ & \\
\hline & Monster: idle, walk, jump & & Monster: idle, walk, jump & & Monster: idle, walk, jump & \\
\hline \multirow{4}{*}{$\begin{array}{c}\text { Stage } \\
4\end{array}$} & Word count: 3 & \multirow{4}{*}{$\begin{array}{l}\text { โจทย์, } \\
\text { ชอล์ก, } \\
\text { ฟิล์ม }\end{array}$} & Word count: 5 & \multirow{4}{*}{$\begin{array}{l}\text { ขาดดุล, บาตรใหญ่, } \\
\text { ปราศรัย, ผลัดเวร, } \\
\text { ลายเซ็น }\end{array}$} & Word count: 5 & \multirow{4}{*}{$\begin{array}{l}\text { อนุสรณ์,อวตาร, } \\
\text { เพชฌฆาต, } \\
\text { เฟอร์นิเจอร์, อโนดาต }\end{array}$} \\
\hline & Alphabet time: $15 \mathrm{~s}$ & & Alphabet time: $12 \mathrm{~s}$ & & Alphabet time: $8 \mathrm{~s}$ & \\
\hline & Word time: $25 \mathrm{~s}$ & & Word time: $30 \mathrm{~s}$ & & Word time: $35 \mathrm{~s}$ & \\
\hline & Monster: idle, walk & & Monster: walk, jump & & Monster: idle, walk, jump & \\
\hline \multirow{4}{*}{$\begin{array}{c}\text { Stage } \\
5\end{array}$} & Word count: 3 & \multirow{4}{*}{$\begin{array}{l}\text { เต๊นท์, } \\
\text { กะทิ, } \\
\text { ชบา }\end{array}$} & Word count: 5 & \multirow{4}{*}{$\begin{array}{l}\text { เวทมนตร์, สร้างสรรค์, } \\
\text { สายสิญจน์, เหตุการณ์, } \\
\text { เลือกสรร }\end{array}$} & Word count: 5 & \multirow{4}{*}{$\begin{array}{l}\text { อินเทอร์เน็ต, } \\
\text { ลาดตระเวน, อัฒจันทร์, } \\
\text { สรรเสริญ, ปาฏิหาริย์ }\end{array}$} \\
\hline & Alphabet time: $12 \mathrm{~s}$ & & Alphabet time: 10s & & Alphabet time: $10 \mathrm{~s}$ & \\
\hline & Word time: $20 \mathrm{~s}$ & & Word time: $25 \mathrm{~s}$ & & Word time: $30 \mathrm{~s}$ & \\
\hline & Monster: walk, fly & & Monster: walk, jump, fly & & Monster: jump, fly & \\
\hline
\end{tabular}

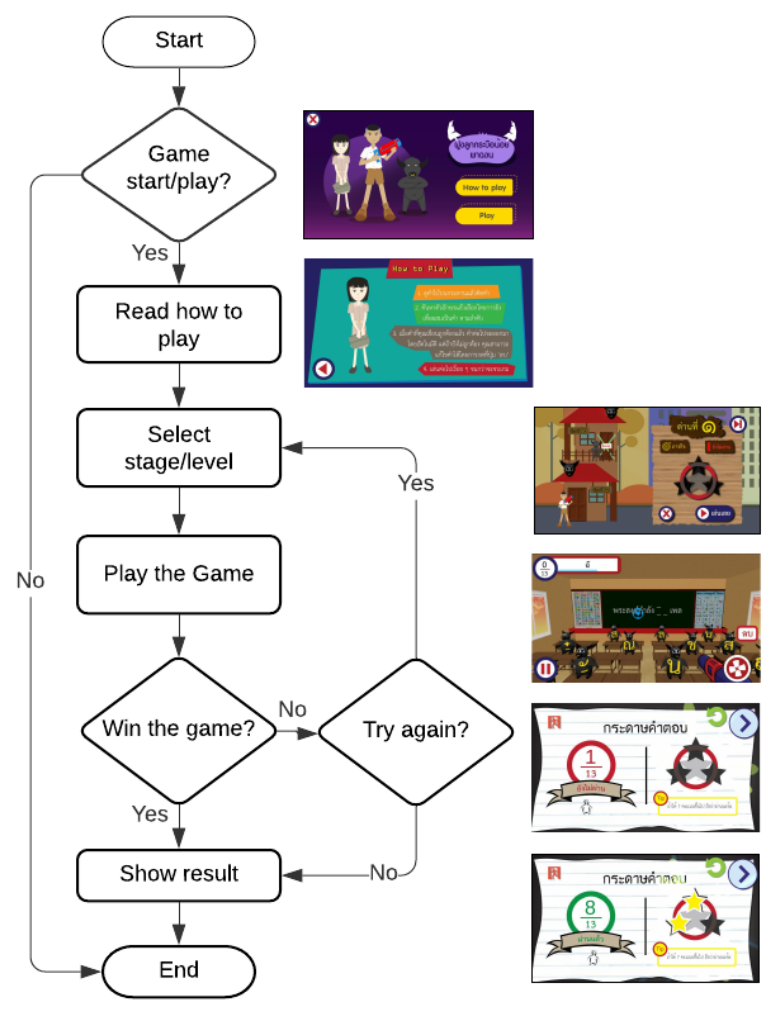

Fig. 3. Game Flow (Flowchart).

As shown in Table II, there are four types of monsters in the game. A standing still (idle) monster will exist since the first stage, a walking monster will start appearing from the second stage onwards, a jumping monster will start appearing from the third stage onwards and a flying monster will start appearing from the fifth stage onwards. The variation of position and movement causes it to be more difficult to aim and shoot accurately. Sometimes the correct letters will be blocked by another monster for some time. These difficulties make the

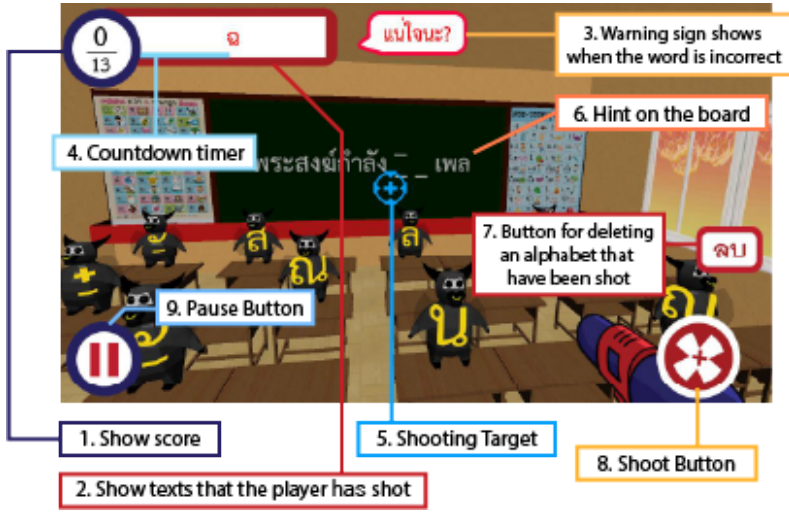

Fig. 4. Screenshot of Gameplay 1.

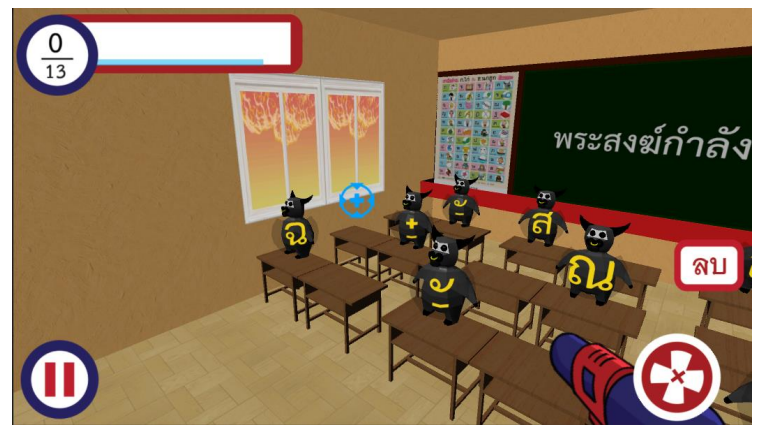

Fig. 5. Screenshot of Gameplay 2.

game more challenging. During the stages, help items will randomly fly into the scene in which players can then choose to shoot and use them. There are two types of help items, first is an item to help increase the time for 15 seconds to complete a word and the other is to stop monsters from moving for a limited time. 


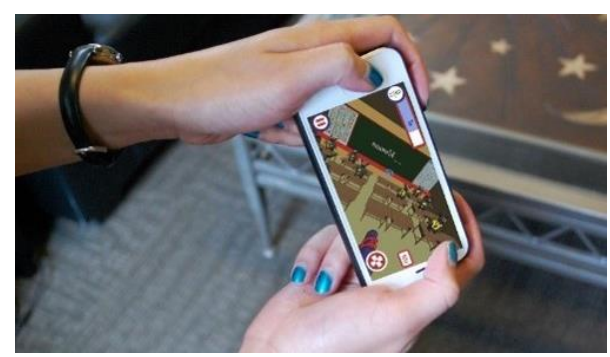

Fig. 6. "The Herd of Calf Teach Thai", 3D Game using a Gyroscope Sensor.

TABLE II. MONSTER

\begin{tabular}{|l|l|l|l|}
\hline Idle & Walk & Jump & Fly \\
\hline IP & Pि & Pि & Pि \\
\hline
\end{tabular}

\section{Evaluation}

The paired sample t-test compares two means that are from the same individual, object, or related units. The two means can represent things like: A measurement is taken at two different times (e.g. pre- and post-test with an intervention administered between the two-time points) [26].

As shown in Table III, the paired sample t-test shows the actual test results. The sample dataset has placement test scores (out of 65 points) for pre- and post-tests (before and after playing the game). In this case, particular interest was paid to the learning outcome after playing the game to determine whether the pre-test or post-test had higher test scores on average. In this case, a paired t-test was used to test if there was a significant difference in the average of the two tests. The post-test scores of the students $(x=54.27$, S.D. $=6.423)$ were significantly higher than the pre-test scores $(x=39.24$, S.D. $=10.380)$. On average, post-test scores were 15.027 points higher than pre-test scores $(95 \%$ CI $[-17.615,-12.439])$ (see Table V).

TABLE III. Pre- And Post-Test Data (Mean and Std)

\begin{tabular}{|r|l|r|r|r|r|}
\hline \multicolumn{7}{|c|}{ Paired Samples Statistics } \\
\hline & & Mean & N & Std. Deviation & Std. Error Mean \\
\hline Pair 1 & pre & 39.24 & 37 & 10.380 & 1.706 \\
\hline & post & 54.27 & 37 & 6.423 & 1.056 \\
\hline
\end{tabular}

Table IV indicates that the mean of the pre- and post-test scores of the students were weakly and positively correlated $(r=0.666, p<0.001)$. As shown in Table $\mathrm{V}$, there was a significant average difference between pre- and post-test scores $(t 36=-11.776, p<0.001)$. The result shows that the game enhanced learning outcomes for the population.

TABle IV. Pre-And Post-Test Scores Correlations

\begin{tabular}{|l|l|l|r|r|}
\hline \multicolumn{5}{|c|}{ Paired Samples Correlations } \\
\hline & & N & Correlation & Sig. \\
\hline Pair 1 & pre \& post & 37 & .666 & .000 \\
\hline
\end{tabular}

\section{Conclusions and Future Perspective}

The development of the puzzle game, "The Herd of Calf teach Thai" to improve students' spelling in Thai was created as a new alternative way of learning about Thai words that are often misspelled or written incorrectly. The game is a firstperson shooter game that plays on mobile devices with the Android operating system. Most players have already played the game "Hangman" which means it does not take much time to learn how to play the game. They can play when gameplay appears with hints also assigned to help players. Then, players search for the missing letters which are shown in the scene. They then shoot the letters sequentially to mix into the correct words. The player can also replay until the condition is met or until the game is over which leads to learning the correct form of words from misspelled words.

The game level design is divided into five stages, and each stage has three levels. The difficulty of the game will change according to the level and stage. The evaluation was undertaken by a class of 37 students under 20 years old in the Department of Animation and Game within the College of Arts, Media, and Technology at Chiang Mai University, Thailand. In this case, a pre-game knowledge test was conducted. The data were then used for statistical testing using a pair sample t-test, and the results show that the game enhanced learning outcomes. Game design is both a science and an art, which has many steps and several approaches. This game has several detailed steps in the game-making process that involved and needed integrated knowledge to produce the game. It is often a challenge for developers to build on knowledge or content in the development of games. The uniqueness of this game is that it is not only entertaining for players, but it also offers players the ability to gain knowledge. Although players may not be able to achieve their goals all at once, they will be able to achieve them through repeated play and recognition. This is considered an important option as it creates creative learning and has the ability to attract a wide range of people.

However, there are still opportunities to develop the game further, including a Gyroscope game controller although this development requires the application of the Google Cardboard Software Development Kit, which is not fully customizable. Causing an error in the section of some impressions, including some art elements of the game can still be developed. Continued development in other word categories such as homonyms, words derived from foreign languages, couplets, etc. or the development in other Thai languages such as the Lanna language, etc. Development of a system to collect playing statistics such as identifying wrong and correct words to do further research in the future. As most game development works on a commercial basis, it is a mobile game on the Android operating system, and an In-App purchase system could be set up so that players can choose to purchase various levels or add-ons in the game through the Google Play Store.

\section{ACKNOWLEDGMENT}

The authors are grateful to teachers in Montfort College, Chiang Mai, Thailand for who provided data that assisted the research, Mr. Panupong Maomoon, and the College of Arts, Media, and Technology, Chiang Mai University for support. 
TABLE V. Pre-and Post-Test Data of the Student

\begin{tabular}{|c|c|c|c|c|c|c|c|c|c|}
\hline \multicolumn{10}{|c|}{ Paired Samples Test } \\
\hline & & \multicolumn{5}{|c|}{ Paired Differences } & \multirow{3}{*}{$\mathbf{t}$} & \multirow{3}{*}{ df } & \multirow{3}{*}{ Sig. (2-tailed) } \\
\hline & & \multirow[t]{2}{*}{ Mean } & \multirow[t]{2}{*}{ Std. Deviation } & \multirow[t]{2}{*}{ Std. Error Mean } & \multicolumn{2}{|c|}{$\begin{array}{l}95 \% \text { Confidence Interval } \\
\text { of the Difference }\end{array}$} & & & \\
\hline & & & & & Lower & Upper & & & \\
\hline Pair 1 & pre-post & -15.027 & 7.762 & 1.276 & -17.615 & -12.439 & -11.776 & 36 & 0.000 \\
\hline
\end{tabular}

\section{REFERENCES}

[1] D. Metev, "How Much Time Do People Spend on Social Media", Retrieved Sep 2, 2020 from https://review42.com/ how-much-time-do-people-spend-on-social-media/,2020.

[2] D. Patel, "Use of Accelerometers and Gyroscopes in Position Sensing," Retrieved Sep,29, 2015 from http://www2.ece.gatech.edu/academic/ courses/ece4007/08fall/ece4007101/al6/Dhaval_Patel_TRP.pdf, 2009.

[3] M. Jotham, M. Bethel, and C. Tarirai, "Students Perception of the Effect of Cognitive Factors in Determining Success in Computer Programming: A Case Study," International Journal of Advanced Computer Science and Applications(IJACSA), 11(7), 2020.

[4] S. Krutmueng, "Often Written Words in Thai: An Analysis of Teaching Results," Journal of Management, Faculty of Management, Lampang Rajabhat University, 7(1), 42-55, 2014.

[5] P. Hui, "Spelling Errors in Thai Made by Chinese Students Learning Thai as a Foreign Language," The Social and Cultural Context of Language Situation in Southeast Asia Vol 22 No 3, 2019.

[6] R. Mishra and N. Kaur, "A survey of spelling error detection and correction techniques," International Journal of Computer Trends and Technology, 4(3), 372-374, 2013.

[7] R. Mitton, "Spelling checkers, spelling correctors and the misspellings of poor spellers," Information Processing and Management, 23(5), 495$505,1987$.

[8] S. Murthy, R. Madi and P. Kumar. "A non-word Kannada spell checker using morphological analyzer and dictionary lookup method," International Journal of Engineering Sciences and Emerging Technologies, 2(2), 43-52, 2012.

[9] S. Verberne, "Context-sensitive spell checking based on word trigram probabilities," (Master's thesis). University of Nijmegen, Netherlands, 2002.

[10] A. Wilcox-O'Hearn, G. Hirst and A. Budanitsky, "Real-word spelling errection with trigrams: A resonsideration of the Mays, Damerau, and Mercer model," Paper presented at the CICLing-2008, Haifa, 2008.

[11] P. Laimanu and W. Arunmanakul, "Analysis of Thai words that are often written incorrectly," Humanities Journal Vol.24 No.2 (July-December 2017) 318-342, 2017.

[12] R. Ueatrirat and N. Sornjitti, "The Analysis of Srinakharinwirot university students' errors in writing the thai language," Pimkanet Journal 15(1) Jan-June 2019 (87-100), 2019.

[13] R. Boonyim, "The Analysis of Causes of Misspelled Words in Thai," The fifth International and national conferences, Rajabhat Research Dec 2-5, 2018 ,Phetchaburi Rajabhat University, Thailand, 2018.
[14] K. Saksrisathaporn and P. Sribunthankul, "A Smartphone game to promote self-learning in chemistry," International Conference Cognition and Exploratory Learning in Digital Age 2019, Cagliari, Italy, pp. 347354, 2019.

[15] K. Becker, "What is the difference between serious games, educational games, and game-based learning," Retrieved Feb 3, 2018 from https: //wp.me/p4Hsb6-1KS, 2016.

[16] L. Grace, "Game Type and Game Genre. Chicago, IL: Illinois Institute of Art," Retrieved August 26, 2020 from http://aii.lgrace.com/ documents/Game_types_and_genres.pdf, 2005.

[17] L. Bautista, "New Video Reimagines Super Mario Bros as a First-Person Shooter Game in Video Games," Retrieve Mar 12, 2020 from https:// www.highsnobiety.com/p/super-mario-bros-first-person-shooter, 2020.

[18] R. C. Lorenz, T. Gleich, J. Gallinat and S. Kühn, "Video game training and the reward system," Frontiers in human neuroscience, No.9, pp 40, 2015.

[19] F. S. B. Andre, N. M. P. Pedro, A. F. F. D. Joo and G. M. S. Frutuoso, "A New Methodology of Design and Development of Serious Games," International Journal of Computer Games Technology, Article ID 817167, 8 pages, 2014.

[20] K. Saksrisathaporn and T. Maneewan, "A Web-based Traveling Game for the Preservation of Lanna Culture," 2012 IEEE Fourth International Conference on Digital Game and Intelligent Toy Enhanced Learning, Takamatsu, Japan, pp. 52-56, 2012.

[21] E. Klopfer, S. Osterweil and K. Salen, "Moving Learning Games Forward: Obstacles, Opportunities and Openness," MIT The Education Arcade. Cambridge, MA , 2009.

[22] V. Guillén-Nieto and M. Aleson-Carbonell, "Serious games and learning effectiveness: The case of It's a Deal!," Computers and Education, Vol 58, No. 1, pp 435-448, 2012.

[23] R. Dorner, S. Gobel, W. Effelsberg and J. Wiemeyer,"Serious Games Foundations, Concepts and Practice,". Springer International Publishing, 2016.

[24] Paloma. "Trippy, Dreamy Exploration: Gardenarium Released," Retrieved April 3, 2015 from https://www.rockpapershotgun.com/2015/ 04/03/gardenarium-exploration-game-released, 2017.

[25] K. Kiili, "Digital game-based learning: Towards an experiential gaming model," The Internet and higher education, Vol 8, No. 1, 13-24, 2005.

[26] Kent State University Libraries. "SPSS tutorials: Paired Samples tTest," Retrieved Aug 26, 2020, from https://libguides.library.kent.edu/ SPSS/PairedSamplestTest, 2017. 